\section{Looking expectantly to Rio}

\section{London}

ENVIRONMENTAL issues will return to the centre of the international stage in June, when Rio de Janeiro hosts the United Nations Conference on Environment and Development. The summit should see the signing of legally binding international treaties to address two of the world's most pressing environmental problems: the threat of global warming and the erosion of the world's biological diversity.

Since February 1991, negotiators have been struggling to draft a climate change convention that can satisfy all the world's governments. The main stumbling block has been the deep rift between the European Communities (EC) and the United States over the question of setting a target to limit carbon dioxide emissions from the developed world.

A two-week meeting in Geneva that ended on 20 December did little to resolve the impasse and, with only one more negotiating session scheduled before June, the convention seems certain to contain no more than a legal framework under which subsequent action to counter global warming will be agreed - rather like the 1985 Vienna Convention, which preceded the Montreal Protocol on the protection of the ozone layer. A question mark also hangs over the involvement of the former Soviet Union. This is not just an academic question: in 1991, the Soviet Union was still the world's largest producer of oil, even after a 25 per cent decline in production since the late $1980 \mathrm{~s}$. The key factor will be the emerging policy of Boris Yeltsin's Russian government, which controls more than 80 per cent of the former Soviet Union's oil reserves - although it is safe to assume that climate change will not be among Yeltsin's priorities.
Despite disappointment among European governments about the expected failure to draft a climate convention with any real teeth, even the bland document likely to be signed in Rio will commit the world's governments to continued negotiations. And there are some initial signs of a softening attitude from the US Administration. (The departure of White House chief of staff John Sununu, seen as the principal architect of President George Bush's climate change policy, may be an important factor.) At the December meeting in Geneva, the US negotiator, Robert Reinstein, announced that the United States will in 1993 produce a detailed plan of US action to combat global warming (at the federal and state government level and in the private sector). Significantly, Reinstein said that the plan could include some new measures.

Like the climate treaty, the convention on biodiversity is expected to be little more than a bare legal framework, under which future conservation measures will be negotiated. But although environmentalists are disappointed with the progress on climate, those attending the parallel talks on biodiversity are relieved that any progress has been made at all.

Four months ago, says Simon Lyster from the World Wide Fund for Nature, the gulf between the developed and developing countries was so large that the prospect of drafting any treaty in time for the Earth Summit seemed remote. There are still big points of disagreement - for example, over the patenting of biotechnology developed in the industrialized countries but using genes from the developing world - but both camps have begun to compromise.

Peter Aldhous

\section{New research centres}

\section{Sydney}

THE Australian government has announced the formation of $\mathbf{2 0}$ new research centres, a move that will eventually inject up to A \$100 million (\$77 million) into Australian science each year.

The 20 centres represent the second and largest step in the government's Co-operative Research Centre (CRC) programme - a principal part of its effort to boost Australia's advanced industrial base through pure and applied research. As with the first 15 centres of the programme announced last March $(50$ are planned), the government will grant about $\$ 2$ million a year to each centre, provided that the centre partners put in at least the same amount in cash or kind.

After the new centres become fully operational by 1993-94, the government will provide $\$ \mathbf{2 5 0}$ million of the centre's total seven-year budget of $\$ 764$ million. Business will contribute about 16 per cent, with the rest coming from universities, federal and state departments and agencies and medical research institutions.

Almost the only rule in the programme is that each centre must have a university as a partner. However, the research centres, which will be chosen by a special committee of scientists reporting to the Minister for Science, Ross Free, do emphasize certain themes, including materials research, communications and information technology, medical research and molecular engineering, mineral exploration and ore refining, and agriculture. One centre, the Australian Maritime Engineering CRC, will help Australia's fledgling shipbuilding industry. Mark Lawson

\section{Woman to head CSIRO}

\section{Sydney}

THE participation of women in Australian science has been given a boost by the appointment of Professor Adrienne Clarke as chairman of the nation's premier research organization.

Clarke, a molecular biologist, was recently appointed chairman of the Com. monwealth Science and Industrial Research Organization (CSIRO), replacing a former senior state politician, Neville Wran. As the CSIRO is by far the largest and most influential Australian research organization, the appointment makes Clarke one of the nation's most senior scientists.

Clarke, who has been a CSIRO board member since 1986, is head of the University of Melbourne's School of Botany and director of the university's Plant Cell Biology Research Centre.

Her first act as chairman was to announce an extra $A \$ 3$ million for research into an algal bloom infesting a southeastern river system. Mark Lawson 